\title{
Are drought and wildfires turning Mediterranean cork oak forests into persistent shrublands?
}

\author{
Vanda Acácio • Milena Holmgren · Francisco Rego • \\ Francisco Moreira · Godefridus M. J. Mohren
}

Received: 18 January 2008/Accepted: 24 July 2008/Published online: 11 September 2008

(C) The Author(s) 2008. This article is published with open access at Springerlink.com

\begin{abstract}
In the Iberian Peninsula Mediterranean oak forests have been transformed into a mosaic landscape of four main patch-types: forests, savannas, shrublands and grasslands. We used aerial photographs over a period of 45 years (1958-2002) to quantify the persistence and rates of transitions between vegetation patch-types in southern Portugal, where cork oak is the dominant tree species. We used logistic regression to relate vegetation changes with topographical features and wildfire history. Over the 45 years, shrublands have been the most persistent patch-type (59\%), and have been expanding; forests are also persistent $(55 \%)$ but have been decreasing since 1985; savannas and grasslands were less persistent (33\% and 15\%, respectively). Shrublands persistence was significantly correlated with wildfire occurrence, particularly on southern exposures after 1995. In contrast, forest persistence decreased with
\end{abstract}

V. Acácio $(\varangle)$ · G. M. J. Mohren

Forest Ecology and Forest Management Group,

Wageningen University, P.O. Box 47,

6700 AA Wageningen, The Netherlands

e-mail: vanda.acacio@wur.nl

V. Acácio · F. Rego · F. Moreira

Centro de Ecologia Aplicada "Prof. Baeta Neves", Instituto Superior de Agronomia, Universidade Técnica de Lisboa, Tapada da Ajuda, 1349-017 Lisbon, Portugal

M. Holmgren

Resource Ecology Group, Wageningen University, P.O. Box 47, 6700 AA Wageningen, The Netherlands wildfire occurrence, and forests were more likely to change into shrublands where wildfire had occurred after 1995 .

Keywords Alternative stable states . Cistus - Semiarid - Shrub encroachment . Vegetation shifts $\cdot$ Quercus suber

\section{Introduction}

Mediterranean forests are one of the biodiversity "hotspots" on earth (Myers et al. 2000; Olson and Dinerstein 2002). Due to a long history of human disturbance, approximately $70 \%$ of the original Mediterranean forests and shrublands were already destroyed by 1990 (Millennium Ecosystem Assessment 2005). The remaining cover is considered to be in critical or endangered conditions (Olson and Dinerstein 2002; Mooney et al. 2005). Despite this long history of degradation, forest cover has expanded in some areas of Mediterranean Europe since the 1960s after agricultural abandonment and rural exodus (Mazzoleni et al. 2004). In contrast, the opposite trend has apparently taken place in the drier evergreen oak forests of the southern Iberian Peninsula. Here, canopy trees have decayed reducing tree density (Gonçalves 1991; Ferreira 2000; Vicente and Alés 2006), tree seedling mortality is high (Anon 1990; Montero et al. 1994) and xerophytic Cistus 
shrublands have expanded in areas formerly covered by oak forests and savannas (Calvão and Palmeirim 2004).

Since in semi-arid Mediterranean ecosystems, tree seedlings often establish under the shade of adult nurse shrubs and trees (Holmgren et al. 2000; Pulido and Díaz 2003; Castro et al. 2004; Gómez-Aparicio et al. 2004), removal of the original vegetation makes conditions for seedling establishment difficult, resulting in a positive feedback of increasing vegetation loss that can be difficult to reverse (Mulligan et al. 2004). Persistent loss of original vegetation has been described for the five Mediterranean-type regions around the world (e.g. Friedel 1987 for South Africa; Westoby et al. 1989 for Australia; Laycock 1991 for California; Puigdefábregas and Mendizabal 1998 for the Mediterranean Basin; and Holmgren 2002 for Chile).

Succession has traditionally been conceived as a relatively linear process, but evidence from a variety of ecosystems indicates that persistent alternative vegetation or ecosystem states may occur, particularly after disturbances (Friedel 1991; Laycock 1991; Scheffer et al. 2001). In these cases, succession is strongly delayed or practically stopped in a condition called arrested succession (Putz and Canham 1992; Sarmiento 1997).

In the southern Iberian Peninsula, original forests dominated by cork oaks (Quercus suber) and Holm oaks (Quercus ilex) have been transformed into an agroforestry system. Long-term human management has included combinations of clearing, livestock grazing, and ploughing for agriculture cultivation (Joffre et al. 1999; Pulido et al. 2001). During the 1960s socio-economic changes (industrialization, immigration to cities, emigration, and opening of international markets) led to rural exodus and a gradual abandonment of crops and pastures (Joffre et al. 1991; Pinto-Correia 2000).

At present, oak systems in southern Portugal are a mosaic of four types of patches: forests, oak savannas (traditionally known as montados in Portugal and dehesas in Spain), shrublands and grasslands. Oak savannas and grasslands are maintained through grazing and ploughing in the traditional agroforestry system (Marañón 1988; Huntsinger and Bartolome 1992; Díaz et al. 2003). In the absence of human management, the usual pathway of natural succession is through the gradual colonization by different shrub species (pioneer Cistus shrubs, followed by other shrub species like Arbutus and Erica), followed by oak natural regeneration leading eventually to forest recovery (Natividade 1950; Gonçalves 1991). However, under a combination of dry conditions (either drought periods or south facing slopes) and wildfires, forest recovery may be impeded and a transition to Cistus shrublands more likely. The last decades have been characterized by drier conditions (Cabrinha and Santo 2000; Esteban-Parra et al. 2003; Pausas 2004) and a higher wildfire incidence (Pausas 2004; Anon 2006) whereas ploughing and livestock grazing have tended to decrease in Portugal (Alves et al. 2003; Pinto-Correia and Vos 2004).

In this paper, we quantify the rate of change between vegetation patch-types (cork oak forests, cork oak savannas, shrublands and grasslands) in the Mediterranean oak forests of southern Portugal during 45 years (1958-2002) and assess the role of drought and wildfire to explain these transitions. We use aerial photographs and a Geographic Information System (GIS) to quantify the persistence of vegetation patch-types and the rates of transitions between them. We project our results for the coming decades and discuss the forest changes in southern Portugal in relation to the trends described for other European Mediterranean regions.

\section{Materials and methods}

Study area

The study area is located in Serra do Caldeirão, a mountain ridge in the northeastern part of the Algarve province, southern Portugal, with an approximate area of 11,000 ha. Climate is Mediterranean, with an average annual temperature of $16.6^{\circ} \mathrm{C}$ and average annual precipitation of $900 \mathrm{~mm}$ (45-year period: 1958-2002, Barranco do Velho station). Altitude ranges from 146 to $588 \mathrm{~m}$. Soil type is homogeneous, consisting mainly of schist lithosols (soils with hard rock at less than $10 \mathrm{~cm}$ depth). These soils are shallow, with low fertility and prone to erosion. Cork oak is the dominant tree species and cork extraction represents the main economic activity for local people. Our study area is one of the most continuous remnants of cork oak forests of southern Portugal. 
Image processing

We used hardcopy aerial photographs and digital orthophotos (rectified copy of an original aerial photograph) from five different years covering a 45-year period: 1958 (scale 1:26,000), 1972 (scale 1:8,000), 1985 (scale 1:5,000), 1995 (scale 1:40,000) and 2002 (scale 1:5,000). Aerial photographs (1958, 1972 and 1985) were previously scanned and then orthorectified and georeferenced with ENVI 3.4 (Anon 2001a) in order to produce geometrically correct images and project them to the same coordinates reference as the digital orthophotos (1995 and 2002) (Transverse Mercator projection, datum WGS84). Digital elevation models with a spatial resolution of $8 \mathrm{~m}$ were used for altitude coordinates (orthorectification process), and ground control points (between 10 and 15 per photo) were taken from the 2002orthophoto for map coordinates (georeferentiation process). We obtained a RMS Error of about $10 \mathrm{~m}$.

Photo interpretation and land cover classification

We used a regular $0.5 \times 0.5 \mathrm{~km}$ grid of 441 points covering the entire study area, and photo interpreted on screen a 50 m-radius circle (sampling unit) around each photographic point. Photo interpretation was performed on a photo-by-photo basis. The grid was created with Arcview GIS 3.2 (Anon 1999) and laid over the aerial photographs and orthophotos (imported into the GIS as scanned images). Our grid has a resolution higher than the usual $4 \times 4 \mathrm{~km}$ grids used for monitoring forest conditions in Europe and allows detecting changes in vegetation types (Köhl et al. 1994). Systematic point sampling is commonly used in forest inventory and gives better estimates than simple random sampling for large areas. Each of the 441 sampling units was classified into one of the following five vegetation patch-types for each image year:

1. cork oak forests with high cork oak density (more than 100-150 trees/ha) and a diverse shrubby layer (e.g. Arbutus unedo, Viburnum tinus, Erica arborea, Pistacia lentiscus, Rhamnus alaternus, Phillyrea latifolia); this class corresponds to a tree cover higher than $30 \%$;

2. cork oak savannas where cork oak density is lower than in forest patches (usually less than 100 trees/ha) with sparse shrubs in the understory; this class corresponds to a tree cover between $10 \%$ and $30 \%$;

3. shrublands dominated by Cistus ladanifer shrubs, pure or mixed with Ulex argenteus, Genista hirsuta and Lavandula stoechas shrubs; in this class, less than $10 \%$ of the sampling unit is covered by trees;

4. grassland patches dominated by cultivated croplands, semi-natural pastures, or fallow land; in this class, less than $10 \%$ of the sampling unit is covered by trees.

5. others (e.g. plantations, pine forests, eucalyptus forests, riparian forests, and urban).

When more than one vegetation patch-type occurred in a sampling unit, it was classified based on the predominant type. Sampling units with only one type of patch-type were predominant (more than $50 \%$ of the total units) and when not, we could usually clearly assign one dominant class to each unit. We used tree cover percent rather than tree density since in many cases it was not possible to count the number of trees on the images. Boundaries for forest density (10\% and 30\% of ground cover) follow the National Forest Inventory norms (Anon 2001b).

Before photo classification (2003), we visited the study area several times to recognize the different vegetation types and compare them with the patterns on the aerial photos of 2002. Photo interpretation was carried out by a group of four persons and results were cross-validated within the group. Approximately $10 \%$ of the sampling units were validated in the field.

Accuracy assessment of land cover classification

Accuracy assessment was evaluated with the calculation of the error matrix (Walsh and Burk 1993). The error matrix allows us to quantify the overall accuracy of the land cover classification procedure, dividing the number of units in the diagonal cells of the matrix by the total number of field-validated units. It allows us also to estimate the probabilities of classification of a unit of class $i$ in class $j$, as $n_{i j} / n_{j}$ (where $i$ represents the observed class, $j$ the predicted class, and $n_{j}$ the sum of all training observations predicted as class $j$ ). Overall accuracy was about $82 \%$. The highest omission error occurred in savannas $(0.4)$ due to confusion with cork oak forests and 
pines, followed by forests (0.24) and shrublands (0.14), due to confusion with pine forests. On the other hand, pine forests and shrublands showed the highest commission errors ( 0.36 and 0.33 , respectively), confused mainly with cork oak forests.

\section{Quantification of vegetation changes}

The information for each sampling unit was stored as a five-layer Arcview GIS database, where each layer represented the landscape at a single point in time. Five transition matrices (Usher 1981; Rego et al. 1993) were built for the five-year set (1958-1972, 19721985, 1985-1995, 1995-2002), and for 1958-2002 (overall period). We estimated the (1) percentage of land covered by each type of vegetation patch (expressed as the $\%$ of total number of points); (2) transitions between vegetation patch-types by counting the number of sampling units of any vegetation patch-type that changed into any other between two discrete time periods (expressed as percentages); (3) rates of change (percentage of change/year) between vegetation patch-types, dividing the percentage of transitions from one patch-type to another by the total number of years during which the transitions occurred; (4) projection of changes for the coming decades, multiplying the observed rates of transitions for a given period by the number of hectares of each vegetation patch-type registered in 2002, and estimating its area for 2003; multiplying again the estimated area by the transition rates and estimating a new area for the following year; calculations were started in 2002 and were successively repeated until 2050. We projected two scenarios: a conservative one based on the average of the four rates of transition observed for the overall period (1958-1972; 1972-1985; 19851995 ; 1995-2002), and a second one based on the most recent trends (1995-2002). To project such changes we assumed that the probabilities of transitions between vegetation patch-types were constant throughout the whole period of projection, following a Markovian process (Rego et al. 1993).

\section{Correlates of vegetation changes}

Topographical variables (slope and exposure) were derived from digital elevation models (Portuguese Military Geographic Institute) and stored as two Arcview GIS layers. We assigned one class of slope and exposure to each sampling unit based on the most common type. The slope categories were: low to medium (0-20\%); steep (20-30\%); very steep $(>30 \%)$. The exposure categories were: north facing slopes (including NW, N and NE), south facing slopes (including SW, S and SE) and others (E and W).

Wildfire occurrence was available as spatially referenced and digitized data for every year between 1984 and 2002 (General Directorate of Forests). The limits of the burned area per year were stored as an Arcview GIS layer and overlaid with the sampling units in order to identify the sampling units that burned between 1984 and 2002. The maximum number of times a unit was burned in the period 1984-2002 was two.

\section{Statistical analysis}

We overlayed the Arcview GIS layers containing the information on slope, exposure and wildfire occurrence with the layer containing the vegetation transition types (e.g. forest to shrubland) for each time period (1958-1972, 1972-1985, 1985-1995, 1995-2002). We used logistic regression to explore the relative importance of slope steepness, exposure and wildfire occurrence on the observed vegetation changes. We analysed (1) transitions from each vegetation patch-type (except "others") to shrublands and (2) vegetation type persistence (except "others") for each of the 4 periods, yielding a total of 28 models ( 4 persistences plus 3 transitions, times 4 time periods). For each model, the predictor variable took the value 1 if a transition (or persistence) occurred for each sampling unit during the specified period, or 0 if not. Slope categories were ranked from 1 to 3 , respectively for $0-20 \%, 20-30 \%$, and $>30 \%$. Exposure and wildfire (presence/absence) were assumed as categorical variables. Forward stepwise selection was used, and variables entering the model selected based on the likelihood-ratio test (Hosmer and Lemeshow 1989). To check whether the models could be improved, some variables were square-transformed and interactions between all variables explored, using the procedures suggested by Hosmer and Lemeshow (1989). Consequently, we created the simplified dummy variables Exposure_South and Exposure_North, which took the value 1 for the specified exposure and 0 for the others categories. Model goodness of fit was assessed through the likelihood 
ratio statistic and the $\chi^{2}$ test. Due to a low number of "occurrences" in some transition types, statistical analyses could not be undertaken.

\section{Results}

Land cover changes

During the 45-year study period there were significant changes in land cover. Between 1958 and 1972, shrublands expanded rapidly (54\% increase) while grassland cover registered a decline of $481 \%$ (Table 1). In those 15 years, shrublands became the patch-type with the highest cover (33.8\%). By 1972, only $4.8 \%$ of the total area was covered by grassland patches which remained as such onwards (Table 1). During the following two decades, shrublands slightly decreased (around $28 \%$ of the total area) to became again the predominant patch-type in 2002 $(32.4 \%)$. Cork oak forests, the most abundant patchtype in 1958 (about 30\%), decreased during the next 45 years to cover around $24.5 \%$ of the area in 2002 (Table 1). Savannas initially expanded but have decreased since 1972 onwards. During the whole period, only shrublands and the category "others" registered net increases $(51.9 \%$ and $62.4 \%$, respectively, Table 1). The high net increase of "others" is mainly due to plantations and pine regeneration and expansion (both sum up about $80 \%$ of the category "others" in 1958 and $90 \%$ in 2002).

Patch-dynamics: persistence and transition rates between vegetation patch-types

The dynamism of this landscape can be better appreciated in Fig. 1 showing the percentage of

Table 1 Temporal changes of vegetation patch-types (\% of total number of sampling units) and net changes from 1958 to 2002

\begin{tabular}{lrrrrrc}
\hline & 1958 & 1972 & 1985 & 1995 & 2002 & $\begin{array}{l}\text { Net changes } \\
1958-2002\end{array}$ \\
\hline Forests & 29.9 & 26.8 & 31.1 & 29.3 & 24.5 & -22 \\
Savannas & 19.7 & 24.9 & 21.5 & 21.1 & 18.6 & -5.9 \\
Shrublands & 15.6 & 33.8 & 28.1 & 27.9 & 32.4 & +51.9 \\
Grasslands & 27.9 & 4.8 & 3.9 & 3.6 & 6.3 & -342.9 \\
Others & 6.8 & 9.8 & 15.4 & 18.1 & 18.1 & +62.4 \\
\hline
\end{tabular}

transitions between vegetation patch-types from 1958 to 2002 in a conceptual state-and-transition model. Forests and shrublands were the most persistent patch-types, contrasting with savannas and grasslands. The largest changes occurred in grasslands, switching mostly to shrublands (40\%), but also to savannas $(25 \%)$ and others (20\%). Other important transitions occurred in savannas, as they changed to shrublands $(28 \%)$ or forests $(23 \%)$. Despite the high persistence of cork oak forests $(55 \%)$, an important fraction became shrublands (20\%).

Forests changed faster into savannas than into shrublands (Fig. 2), but more forest patches changed into shrublands (20\%) than into savannas (13\%) during the overall period (Fig. 1), which indicates that most of these changes are not direct transitions, implying a gradual loss of the tree canopy: forest patches change first into savannas and then these savannas change into shrublands. In any case, forests are changing at an increasing rate since 1985 .

Oak savannas have become shrublands at increasing rates, while less savannas have returned to forests (Fig. 2). Between 1972 and 1984, forests recovered when savannas switched into forests at the highest rate, but since then there has been a clear decreasing trend. At present, savannas change six times faster into shrublands than into forests.

Shrublands have been the most persistent patchtype $(59 \%)$ changing very little into something else (around 7\% into forests, grasslands or savannas) (Fig. 1). The vegetation transition rates indicate that cork oak recruitment seems to be particularly difficult in shrublands. Only $7 \%$ of shrublands changed into savannas and forests compared to $25 \%$ of grasslands changing into savannas, and $23 \%$ of savannas becoming forests (Fig. 1). Grasslands have been transformed mainly into shrublands and in a smaller extent, into savannas (Fig. 1), both at a decreasing rate since 1958 (Fig. 2).

Projection of changes for the coming decades

Projection of our results for the coming decades shows an increase of shrublands and a decrease of forests and savannas (Fig. 3). Obviously, the conservative approach based on the transition rates for the 45 years (1958-2002) suggests smoother changes than the one projected using the most recent rates (1995-2002). It is interesting to notice that present 


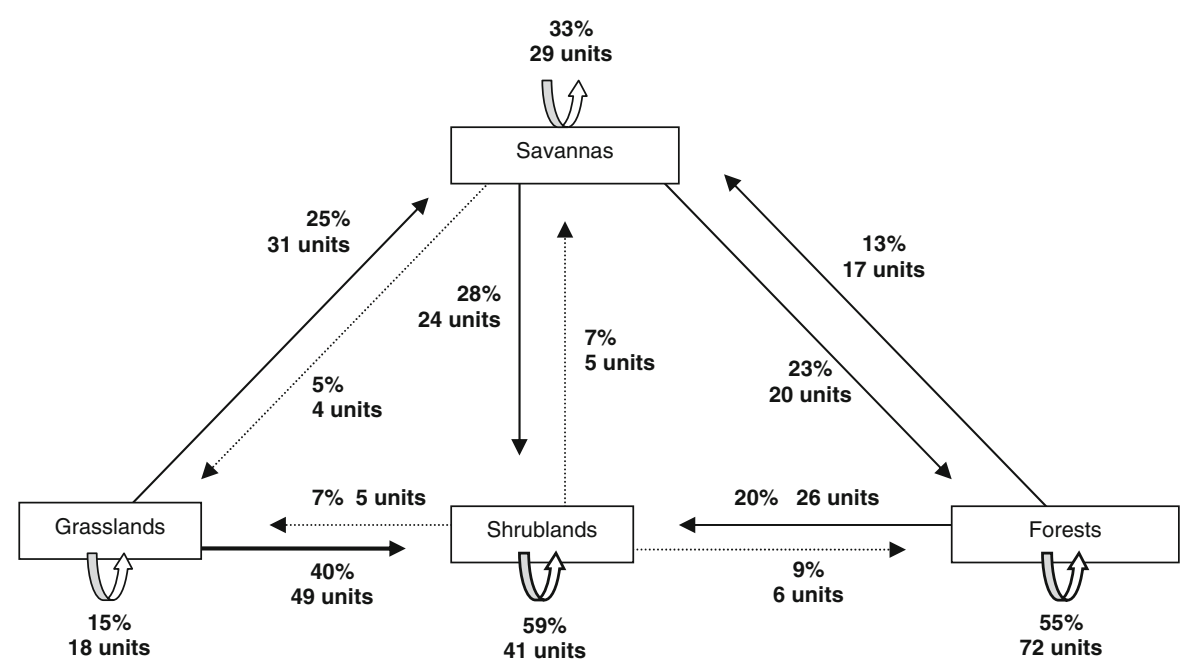

Fig. 1 State-and-transition model with observed transitions (\%) between vegetation patch-types in southern Portugal (1958-2002). Changes (\% and number of units) for each patch-type are based on the number of sampling units classified as that patch-type in 1958 that changed (or remained) in 2002.
Dotted lines indicate frequency of transitions $<10 \%$. The $\%$ of transitions from each patch-type to "others" are not shown in the Figure; such $\%$ is the difference between $100 \%$ and the total $\%$ of transitions shown from each patch-type
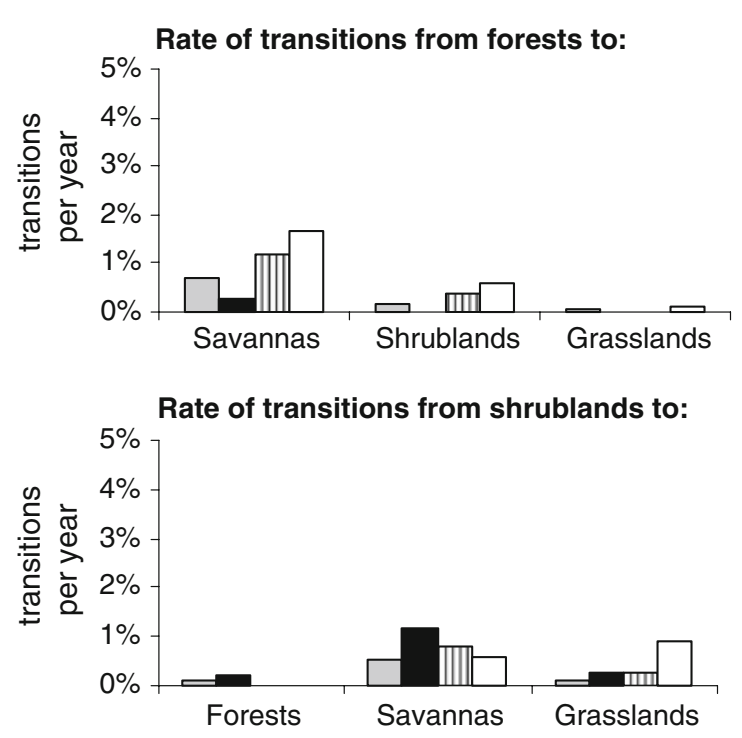

Rate of transitions from savannas to:

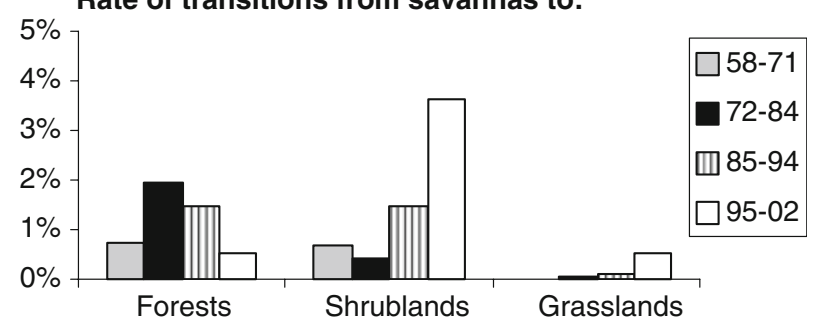

Rate of transitions from grasslands to:

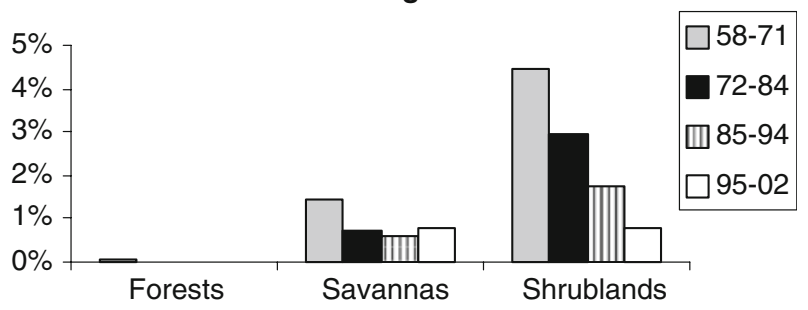

Fig. 2 Rate of transitions (\% of transitions per year) from each vegetation patch-type to the others (1958-2002)

rates of transition suggest a future increase in grassland patches, which have increased in the last years (see Fig. 2).

The role of topographic variables and wildfire history on vegetation changes

Forest persistence increased with slope steepness during each time period and decreased with wildfire occurrence since 1985 (Table 2). In contrast, shrubland persistence was significantly correlated with wildfire, particularly on southern exposures after 1995 (Table 2). Grassland persistence was higher on lower slopes and particularly when they were located on southern exposures. Savanna persistence was not influenced by any studied variable except during the period 1958-1972, when they were more likely to persist on steeper and no north-facing slopes 


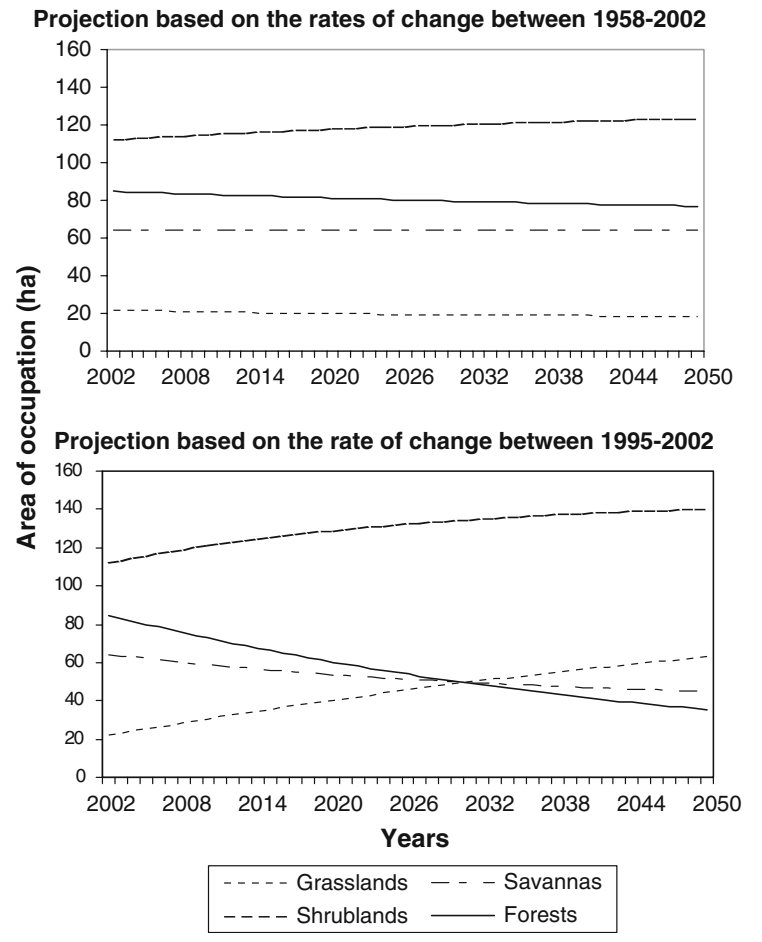

Fig. 3 Projection of the area (ha) of occupation of vegetation patch-types for 2002-2050, based on the rates of change observed in 1958-2002 (average) and 1995-2002

(Table 2). Of the three potential patch transitions to shrublands, wildfire increased the probability of transition from forests to shrublands in the period 1995-2002, and grasslands were more likely to change into shrublands if located on lower slopes (until 1985). None of the studied variables influenced the transitions from savannas to shrublands (Table 2).

\section{Discussion}

Overall vegetation changes

Shrubland encroachment has been the most conspicuous landscape change in this part of the southern Iberian Peninsula since 1958 when forest understory use for agriculture and pastures was abandoned in many areas (Alves et al. 2003; Pinto-Correia and Vos 2004). Shrublands increased during the last 45 years at the expense of the other vegetation patch-types. Persistent shrub encroachment has also been found in other Mediterranean ecosystems like the Italian 'macchia' (Pignatti 1978; Scarascia-Mugnozza et al.
2000), the cork oak forests of southern France (Trabaud and Galtié 1996), as well as in the Spanish dehesas, an oak savanna system comparable to the Portuguese montados (Huntsinger and Bartolome 1992). In contrast, forest expansion has been described as the dominant landscape change throughout Mediterranean Europe since the 60s (Mazzoleni et al. 2004). There, shrublands are usually reported as intermediate phases prior to forest recovery (Mazzoleni et al. 2004).

Shrublands and forests are more persistent vegetation types (59 and 55\% respectively) than savannas $(33 \%)$ and grasslands $(15 \%)$. The main vegetation changes along the study period (above $20 \%$ in Fig. 1) were the (a) replacement of grasslands by shrublands, savannas and others, (b) replacement of savannas by shrublands and forests, and (c) replacement of forests by shrublands. Grasslands decreased in more than $300 \%$ and since 1972 only $4.8 \%$ of the total area has remained covered by grassland patches, probably maintained for family subsistence close to human settlements.

\section{Patch-type dynamics}

Shrubland persistence was positively correlated with wildfire occurrence, particularly on southern exposures since 1995. Shrublands usually grow in very dry and degraded soil conditions and are commonly dominated by Cistus spp., especially on south-facing slopes (Nuñez et al. 1986; Diniz 1994; Seng and Deil 1999). In addition, Cistus shrublands are active pyrophites, thus their persistence can be supported by a positive feedback mechanism triggered by frequent wildfires. Particularly, Cistus ladanifer is a highly flammable species due to its external resins (Trabaud 1981). Our results point towards the same pattern with a tendency of Cistus ladanifer shrublands to be maintained by wildfire occurrence and on south-facing slopes, where conditions are drier and more limiting for seedling recruitment and cork oak survival. Cistus shrubs will survive wildfires and maintain themselves as long as the interval between successive fires is higher than the time that is needed for seed bank restoration. Cistus seed banks seem to be restored every 3 years for Cistus ladanifer in Spain (Ferrandis et al. 1999) or only 2 years for Cistus sp. in California (Montgomery and Strid 1976), which is much less than the time interval between successive fires in the region. 
Table 2 Results of multivariate logistic regression to predict persistence and transitions between vegetation patch-types

\begin{tabular}{|c|c|c|c|c|}
\hline & 1958-1972 & 1972-1985 & 1985-1995 & 1995-2002 \\
\hline $\mathrm{Fo} \rightarrow \mathrm{Sr}$ & $n=3(*)$ & $n=0(*)$ & $n=5$ & $\begin{array}{l}\text { Fire }(+) P=0.057 \\
n=5\end{array}$ \\
\hline $\mathrm{Sa} \rightarrow \mathrm{Sr}$ & $\begin{array}{l}- \\
n=8\end{array}$ & $\begin{array}{l}- \\
n=6\end{array}$ & $\begin{array}{l}- \\
n=13\end{array}$ & $\begin{array}{l}- \\
n=26\end{array}$ \\
\hline $\mathrm{Gr} \rightarrow \mathrm{Sr}$ & $\begin{array}{l}\text { Slo }(-) P=0.049 \\
n=77\end{array}$ & $\begin{array}{l}\text { Slo }(-) P=0.003 \\
n=8\end{array}$ & $n=3(*)$ & $n=1(*)$ \\
\hline $\mathrm{Sr} \rightarrow \mathrm{Sr}$ & $\begin{array}{l}- \\
n=57\end{array}$ & $\begin{array}{l}- \\
n=108\end{array}$ & $\begin{array}{l}\text { Fire }(+) P=0.007 \\
n=97\end{array}$ & $\begin{array}{l}\text { Fire } \times \text { Asp_S }(+) P=0.004 \\
n=105\end{array}$ \\
\hline $\mathrm{Fo} \rightarrow \mathrm{Fo}$ & $\begin{array}{l}\text { Slo }(+) P=0.002 \\
n=106\end{array}$ & $\begin{array}{l}\text { Slo }(+) P<0.001 \\
n=105\end{array}$ & $\begin{array}{l}\text { Slo }(+) P=0.002 \\
\text { Fire }(-) P=0.026 \\
n=115\end{array}$ & $\begin{array}{l}\text { Slo }(+) P<0.001 \\
\text { Fire }(-) P=0.027 \\
n=103\end{array}$ \\
\hline $\mathrm{Sa} \rightarrow \mathrm{Sa}$ & $\begin{array}{l}\text { Slo } \times \text { Asp } P=0.026 \\
\text { Slo } \times \text { Asp_O }(+) \\
\text { Slo } \times \text { Asp_S }(+) \\
n=67\end{array}$ & $n=66$ & $n=66$ & $n=58$ \\
\hline $\mathrm{Gr} \rightarrow \mathrm{Gr}$ & $\begin{array}{l}\text { Slo }(-) P<0.001 \\
n=19\end{array}$ & $\begin{array}{l}\text { Slo }(-) P=0.001 \\
\text { Slo } \times \text { Asp_S }(-) P=0.002 \\
n=11\end{array}$ & $\begin{array}{l}\text { Slo }(-) P=0.002 \\
\text { Slo } \times \text { Asp_S }(-) P=0.001 \\
n=12\end{array}$ & $\begin{array}{l}\text { Slo }(-) P=0.003 \\
\text { Slo } \times \text { Asp_S }(-) P=0.002 \\
n=14\end{array}$ \\
\hline
\end{tabular}

For each combination of transition/persistence type and time period, variables entering the model are shown, as well as their direction of association (+/-) with the response variable, and significance (Likelihood ratio test). Vegetation types include shrublands (Sr), forests (Fo), savannas (Sa) and grasslands (Gr). Variables include slope (Slo), exposure (Asp), exposure south (Asp_S), exposure "others"- - east or west (Asp_O) and Wildfire (Fire). $n=$ number of occurrences. The asterisk (*) signals low frequency-transitions that were not considered for analysis. For all analyses, sample size was 441 sample units

Shrublands expanded initially at grassland patches. The rate of this transition has been decreasing across time, and was particularly evident on flatter areas until 1985, perhaps because deeper soils contribute to faster shrub encroachment, after the abandonment of agriculture and pastures. In contrast, cork oak forests have been decreasing since 1985. Although cork oak forests can be highly persistent, a significant proportion $(20 \%)$ has turned into shrublands. Our results showed that forests persisted longer on steeper slopes, likely because they were less accessible to human interventions. After 1995, we observe a clear effect of wildfire occurrence on tree density: when no wildfire occurs forests persist at steeper slopes, whereas occurrence of wildfire causes tree loss and conversion of forests into shrublands. Although the cork oak is partially protected against fires by bark insulation and is able to resprout after fire, frequent or intense wildfires may kill adult trees, especially if wildfires occur immediately after cork extraction (Cabezudo et al. 1995; Pausas 1997; Moreira et al. 2007), which takes place in the summer, when the wildfire season begins in Mediterranean Europe. In addition, the rate of tree recovery might decrease with increasing wildfire frequency because of lower resprouting success and higher oak seedling mortality (DíazDelgado et al. 2002).

After an initial recovery following agriculture abandonment (1958-1984), savannas have also been changing into shrublands since 1985 . Initial cork oak recruitment in old fields at the beginning of abandonment was also found in Eastern Spain, followed by shrub encroachment (Pons and Pausas 2006). Shrub encroachment could be limiting tree recruitment onwards, especially on drier conditions. Our results suggest that savannas were more likely to persist in steeper slopes and drier exposures that did not face north. 
Forests and savannas have been converted into shrublands at an increasing rate. Forest replacement by shrublands has been positively associated with wildfire incidence since 1995, but the transition of savannas to shrublands was not associated with any studied variable. Drought has probably played an important role on the replacement of savannas by shrublands: savannas have lower tree density and therefore seedlings and saplings are exposed to higher irradiance and water stress than in forests. Patches converted into shrublands have been highly persistent and rarely switched into a different vegetation type. Experimental evidence indicates that shrubland persistence can be explained by oak seedling recruitment limitation in multiple phases (Acacio et al. 2007).

Grassland persistence has been higher on lower slopes, probably because these are the areas where farming activities are maintained. Grasslands tend to persist on southern slopes likely due to soil and climatic conditions slowing successional changes.

Mechanisms limiting forest recovery

Limited cork oak recruitment in shrublands might be more related to seedling recruitment than to seed availability. Indeed our transition rates from grasslands to savannas and from savannas to cork oak forests suggest similar probabilities of cork oak recruitment in grasslands and savannas patches despite the likely difference in seed availability between these two types of patches (Pulido and Díaz 2003). Dense Cistus stands may preclude cork oak regeneration in different ways. It is known that Cistus shrubs have allelopathic effects, inhibiting seedling germination and survival (Chaves and Escudero 2001; Lobón et al. 2002). There could be also limitations in acorn dispersal, increased acorn predation (Herrera 1995; Leiva and Fernández-Alés 2003), or limitations in seedling germination and or survival under the dense and dry shrub cover (Retana et al. 1999).

Experimental work at the study area showed that different mechanisms of oak recruitment limitation (namely, seed source limitation, dispersal limitation, germination limitation, and establishment limitation) were significantly more severe in Cistus shrublands than in oak forests and savannas, hence cork oak seedling recruitment in shrubland was impeded in multiple ways (Acacio et al. 2007). Cork oak recruitment is also rare in the shrublands of eastern Spain
(Pons and Pausas 2006) where very low oak seedling survival rates have been found under Cistus shrubs (Gómez-Aparicio et al. 2004; Pulido and Díaz 2005).

Cork oak forests under climate change

Mean annual temperatures and rainfall intensity with erosive potential (number of days with rainfall $>13 \mathrm{~mm}$ ) have clearly increased in southern Portugal since 1972 (Water Institute, National Meteorological Institute and Regional Coordination Commission of Algarve).

The increase of mean annual temperature and rainfall extremes during the last decades follows the trends predicted by present climate change models projecting a higher frequency of droughts and intense rain events for Mediterranean-climate regions (Cubash et al. 1996; McCarthy et al. 2001). Under this scenario, wildfire frequency and soil erosion are expected to intensify. This will undoubtedly reduce forest cover and limit regeneration, while facilitating shrubland persistence and expansion. Comparable results have been found in Spanish and French cork oak forests where higher wildfire frequency was also related to a decrease in forest resilience and their switch into shrublands (Díaz-Delgado et al. 2002; Trabaud and Galtié 1996, respectively). Also modelling results show that increasing wildfire frequency promotes shrublands dominated by Cistus and limits Quercus growth (Pausas and Vallejo 1999). Moreover, Cistus species are well adapted to drought through physiological responses (Werner et al. 1998). In addition to drought and wildfires, cork oak mortality has been correlated to pathogens whose incidence might interact with climatic conditions (Moreira and Martins 2005).

Recent climate simulation models also predict a very severe impact of climate change on cork oak forests and savannas in Portugal due to difficulties in regeneration and increase of tree mortality, especially in the south of the country, while shrublands are expected to expand at the expense of cork oak areas (Pereira et al. 2002). Such future trends are shown in our projections, especially the one based on the most recent rates. Predictions based on the most recent trends are more reliable than the ones based on the average rate (1958-2002), since transitions are more likely to change over time. Nevertheless, we probably underestimate the changes by assuming that the probabilities of transitions follow a Markovian 
process, which is clearly unlikely given the varying transition rates from 1958 to 2002.

Our findings indicate a serious threat to the cork oak production system in southern Portugal, which is the basis of the local economy and has high conservation value, protected by European Union (Habitats Directive 92/43/EEC). The combination of increasing temperatures and increasing wildfire frequency has contributed to the expansion of shrublands in previous cork oak dominated areas. Shrublands may represent an alternative persistent state of lower vegetation biomass on the most degraded soils and dry areas, where conditions for forest recovery become extremely difficult. If observed trends continue, the sustainability of this unique landscape of the Western Mediterranean area will be in jeopardy.

Acknowledgements This research was funded by the Portuguese Foundation for Science and Technology (Fundação para a Ciência e a Tecnologia), fellowship number SFRH/BD/5008/2001. We also would like to thank to: the Portuguese Military Geographic Institute, Portuguese Geographic Institute and National Pulp Industry Association for kindly providing the photographic material used in this project; Rute Palmeiro, Susana Pereira, Tiago Dias and Miguel Porto for the help with the photo interpretation work; João Carreiras and Filipa Marques for the help with ENVI and Arcview software; Patrick Jansen for insightful comments; and Maria José Vasconcelos for kindly providing information on burned areas. M. Holmgren thanks the Dutch NWO Meervoud Programme (836.05.021).

Open Access This article is distributed under the terms of the Creative Commons Attribution Noncommercial License which permits any noncommercial use, distribution, and reproduction in any medium, provided the original author(s) and source are credited.

\section{References}

Acacio V, Holmgren M, Jansen PA et al (2007) Multiple recruitment limitation causes arrested succession in Mediterranean cork oak systems. Ecosystems (NY, Print) 10:1220-1230. doi:10.1007/s10021-007-9089-9

Alves AL, de Carvalho NS, da Silveira SC et al (2003) O abandono da actividade agrícola. Grupo de Trabalho Agro-Ambiental. Acção 2.2.1. Ministério da Agricultura, Desenvolvimento Rural e Pescas, Lisboa

Anon (1990) Inventário florestal do sobreiro. Estudos e Informacão n: 300. Direcção Geral das Florestas, Lisboa

Anon (1999) Arcview GIS 3.2. Environmental Systems Research Institute. Redlands, USA

Anon (2001a) ENVI 3.4. Research systems. Boulder, USA

Anon (2001b) Inventário florestal nacional: Portugal continental. 3. ${ }^{a}$ revisão 1995-1998. Relatório final. Direcção Geral das Florestas, Lisboa
Anon (2006) Incêndios Florestais. Relatório de 2005. Direcção Geral dos Recursos Florestais, Lisboa

Cabezudo B, La Torre AP, Nieto JM (1995) Regeneración de un alcornocal incendidado en el Sur de España (Istán, Málaga). Acta Bot Malacitana 20:143-151

Cabrinha V, Santo FE (2000) Drought tendencies in mainland Portugal. In: Wilhite DA, Sivakumar MVK, Wood DA (eds) Early warning systems for drought preparedness and drought management. Proceedings of an expert group meeting. Lisbon

Calvão T, Palmeirim JM (2004) Mapping Mediterranean scrub with satellite imagery: biomass estimation and spectral behaviour. Int J Remote Sens 25:3113-3126. doi: 10.1080/01431160310001654978

Castro J, Zamora R, Hódar JA et al (2004) Benefits of using shrubs as nurse plants for reforestation in Mediterranean mountains: a 4-year study. Restor Ecol 12:352-358. doi: 10.1111/j.1061-2971.2004.0316.x

Chaves S, Escudero T (2001) Plant growth inhibiting flavonoids in exudates of Cistus ladanifer and in associated soils. J Chem Ecol 27:623-631. doi:10.1023/A:1010388905923

Cubash U, Von Storch H, Waskewitz J et al (1996) Estimates of climate change in Southern Europe derived from dynamical climate model output. Clim Res 7:129-149. doi: $10.3354 / \mathrm{cr} 007129$

Díaz M, Pulido FJ, Marañón T (2003) Diversidad biológica en los bosques mediterráneos ibéricos: relaciones con el uso humano e importancia para la sostenibilidad de los sistemas adehesados. In: Campos P, Montero G (eds) Beneficios comerciales y ambientales de la repoblación y la regeneración del arbolado del monte mediterráneo. CIFOR-INIA, Madrid

Díaz-Delgado R, Lloret F, Pons X et al (2002) Satellite evidence of decreasing resilience in Mediterranean plant communities after recurrent wildfires. Ecology 83:2293-2303

Diniz AC (1994) Os solos do montado e aptidão suberícola nos concelhos de Grândola, Santiago do Cacém e Sines. Correlações com a morte prematura do sobreiro. Silva Lusit 2:247-267

Esteban-Parra MJ, Pozo-Vázquez D, Rodrigo FS et al (2003) Temperature and precipitation variability and trends in Northern Spain in the context of the Iberian Peninsula Climate. In: Bolle HJ (ed) Mediterranean climate variability and trends. Springer Verlag, Berlin

Ferrandis P, Herranz JM, Martínez-Sánchez JJ (1999) Effect of fire on hard-coated Cistaceae seed banks and its influence on techniques for quantifying seed banks. Plant Ecol 144:103-114. doi:10.1023/A:1009816309061

Ferreira F (2000) The cork oak condition in Portugal. In: Oszako T, Delatour C (eds) Recent advances on oak health in Europe. Forest Research Institute, Warsaw

Friedel MH (1987) A preliminary investigation of woody plant increase in the Western Transvaal and implications for veld assessment. J Grassl Soc S Afr 4:25-30

Friedel MH (1991) Range condition assessment and the concept of thresholds: a viewpoint. J Range Manage 44(5):422-426. doi:10.2307/4002737

Gómez-Aparicio L, Zamora R, Gómez JM et al (2004) Applying plant facilitation to forest restoration in Mediterranean ecosystems: a meta-analysis of the use of shrubs as nurse plants. Ecol Appl 14:1128-1138. doi:10.1890/03-5084 
Gonçalves J (1991) Fitocenoses espontâneas dos sobreirais alentejanos: factores ambientais e dinâmica da vegetação associada a condições de mortalidade das árvores. Relatório Final do Curso de Eng. ${ }^{\circ}$ Silvicultor. Instituto Superior de Agronomia. Universidade Técnica de Lisboa, Lisboa

Herrera J (1995) Acorn predation and seedling production in a low-density population of cork oak (Quercus suber L.). For Ecol Manage 76:197-201. doi:10.1016/0378-1127 (95)03566-S

Holmgren M (2002) Exotic herbivores as drivers of plant invasion and switch to ecosystem alternative states. Biol Invasions 4:25-33. doi:10.1023/A:1020535628776

Holmgren M, Segura AM, Fuentes ER (2000) Limiting mechanisms in the regeneration of the Chilean matorral: experiments on seedling establishment in burned and cleared mesic sites. Plant Ecol 147:49-57. doi:10.1023/ A: 1009804726307

Hosmer DW, Lemeshow S (1989) Applied logistic regression. Wiley, New York

Huntsinger L, Bartolome JW (1992) Ecological dynamics of Quercus dominated woodlands in California and southern Spain: a state transition model. Vegetatio 99-100:299305. doi:10.1007/BF00118237

Joffre R, Hubert B, Meuret M (1991) Les systèmes agro-sylvopastoraux méditerranéens: enjeux et réflexions pour une gestion raisonnée. Dossier MAB 10, UNESCO, Paris

Joffre R, Rambal S, Ratte JP (1999) The dehesa of southern Spain and Portugal as a natural ecosystem mimic. Agrofor Syst 45:57-79. doi:10.1023/A:1006259402496

Köhl M, Innes JL, Kaufmann E (1994) Reliability of differing densities of sample grids used for the monitoring of forest condition in Europe. Environ Monit Assess 29:201-220. doi:10.1007/BF00547987

Laycock WA (1991) Stable states and thresholds of range condition on North American rangelands: a viewpoint. J Range Manage 44:427-433. doi:10.2307/4002738

Leiva MJ, Fernández-Alés R (2003) Post-dispersive losses of acorns from Mediterranean savannah-like forests and shrublands. For Ecol Manage 176:265-271. doi:10.1016/ S0378-1127(02)00294-3

Lobón NC, Gallego JC, Díaz TS et al (2002) Allelopathic potential of Cistus ladanifer chemicals in response to variations of light and temperature. Chemoecology 12:139-145. doi:10.1007/s00012-002-8339-0

Marañón T (1988) Agro-sylvo-pastoral systems in the Iberian Peninsula: dehesas and montados. Rangelands 10:255-258

Mazzoleni S, Di Pasquale G, Mulligan M et al (2004) Recent dynamics of the Mediterranean vegetation and landscape. Wiley, Chichester

McCarthy JJ, Canziani OF, Leary NA et al (2001) Climate change 2001: impacts adaptation and vulnerability. Cambridge University Press, Cambridge

Millennium Ecosystem Assessment (2005) Ecosystems and human well-being: synthesis. Island Press, Washington

Montero G, Torres E, Cañellas I (1994) Regeneración de alcornocales. Síntesis bibliográfica. Ecologia 8:271-283

Montgomery KR, Strid TW (1976) Regeneration of introduced species of Cistus (Cistaceae) after fire in Southern California. Madrono 23:417-427
Mooney H, Cropper A, Reid W (2005) Confronting the human dilemma. Nature 434:561-562. doi:10.1038/434561a

Moreira AC, Martins MS (2005) Influence of site factors on the impact of Phytophthora cinnamomi in cork oak stands in Portugal. For Pathol 35:145-162. doi:10.1111/j.14390329.2005.00397.x

Moreira F, Duarte I, Catry F, Acácio V (2007) Cork extraction as a key factor determining post-fire cork oak survival in a mountain region of southern Portugal. For Ecol Manage 253:30-37. doi:10.1016/j.foreco.2007.07.001

Mulligan M, Burke SM, Concepción Ramos M (2004) Climate change, land-use change and the "desertification" of Mediterranean Europe. In: Mazzoleni S, Di Pasquale G, Mulligan $\mathrm{M}$ et al (eds) Recent dynamics of the Mediterranean vegetation and landscape. Wiley, Chichester

Myers N, Mittermeier RA, Mittermeier CG et al (2000) Biodiversity hotspots for conservation priorities. Nature 403:853-858. doi:10.1038/35002501

Natividade JV (1950) Subericultura. Ministério da Economia, Lisboa

Nuñez E, Cabzas J, Escudero JC (1986) Relación de matorrales en la formación de dehesas. Función de la jara, valoración de su biomasa y su utilización industrial. In: Palacín C, Bellido M (eds) Conservación y desarrolo de las dehesas portuguesa y española. Ministerio de Agricultura, Pesca y Alimentación, Badajoz

Olson DM, Dinerstein E (2002) The global 200: priority ecoregions for global conservation. Ann Missouri Bot Gard 89:199-224. doi:10.2307/3298564

Pausas JG (1997) Resprouting of Quercus suber in NE Spain after fire. J Veg Sci 8:703-706. doi:10.2307/3237375

Pausas JG (2004) Changes in fire and climate in the Eastern Iberian Peninsula (Mediterranean Basin). Clim Change 63:337-350. doi:10.1023/B:CLIM.0000018508.94901.9c

Pausas JG, Vallejo VR (1999) The role of fire in European Mediterranean ecosystems. In: Chuvieco E (ed) Remote sensing of large wildfires in the European Mediterranean basin. Springer Verlag, Berlin

Pereira JS, Correia AV, Correia AP et al (2002) Forests and biodiversity. In: Santos FD, Forbes K, Moita R (eds) Climate change in Portugal. Scenarios, impacts and adaptation measures. SIAM Project. Gradiva, Lisboa

Pignatti S (1978) Evolutionary trends in Mediterranean flora and vegetation. Vegetatio 37:175-185. doi:10.1007/ BF00717651

Pinto-Correia T (2000) Future development in Portuguese rural areas: how to manage agricultural support for landscape conservation? Landsc Urban Plan 50:95-106. doi: 10.1016/S0169-2046(00)00082-7

Pinto-Correia T, Vos W (2004) Multifunctionality in Mediterranean landscapes-past and future. In: Jongman R (ed) The new dimensions of the European landscape. Wageningen EU Frontis Series. Springer, Wageningen

Pons J, Pausas JG (2006) Oak regeneration in heterogeneous landscapes: the case of fragmented Quercus suber forests in the eastern Iberian Peninsula. For Ecol Manage 231:196-204. doi:10.1016/j.foreco.2006.05.049

Puigdefábregas J, Mendizabal T (1998) Perspectives on desertification: western Mediterranean. J Arid Environ 39:209-224. doi:10.1006/jare.1998.0401 
Pulido F, Díaz M (2003) Dinámica de la regeneración natural del arbolado de encina y alcornoque. In: Pulido F, Campos P, Montero G (eds) La gestión forestal de las dehesas. Instituto del Corcho, la Madera y el Carbón, Mérida

Pulido F, Díaz M (2005) Regeneration of a Mediterranean oak: a whole-cycle approach. Ecoscience 12(1):92-102. doi: 10.2980/i1195-6860-12-1-92.1

Pulido FJ, Díaz M, Hidalgo de Trucios H (2001) Size structure and regeneration of Spanish holm oak Quercus ilex forests and dehesas: effects of agroforestry use on their long-term sustainability. For Ecol Manage 146:1-13. doi: 10.1016/S0378-1127(00)00443-6

Putz FE, Canham CD (1992) Mechanisms of arrested succession in shrublands: root and shoot competition between shrubs and tree seedlings. For Ecol Manage 49:267-275. doi:10.1016/0378-1127(92)90140-5

Rego F, Pereira J, Trabaud L (1993) Modelling community dynamics of a Quercus coccifera $\mathrm{L}$. garrigue in relation to fire using Markov chains. Ecol Model 66:251-260. doi: 10.1016/0304-3800(93)90116-A

Retana J, Espelta JM, Gracia M et al (1999) Seedling recruitment. In: Rodà F, Retana J, Gracia CA et al (eds) Ecology of Mediterranean evergreen oak forests. Springer Verlag, Berlin

Sarmiento FO (1997) Arrested succession in pastures hinders regeneration of Tropandean forests and shreds mountain landscapes. Environ Conserv 24:14-23

Scarascia-Mugnozza G, Oswald H, Piussi P et al (2000) Forests of the Mediterranean region: gaps in knowledge and research needs. For Ecol Manage 132:97-109. doi: $10.1016 / \mathrm{S} 0378-1127(00) 00383-2$
Scheffer M, Carpenter S, Foley JA et al (2001) Catastrophic shifts in ecosystems. Nature 413:591-596. doi:10.1038/35098000

Seng M, Deil U (1999) Forest vegetation types in the Serra de Monchique (Portugal): anthropogenic changes of oak forests. Silva Lusitana 7:71-92

Trabaud L (1981) Man and fire: impacts on Mediterranean vegetation. In: Di Castri F, Goodall DW, Specht RL (eds) Ecosystems of the world, vol 11. Mediterranean-type shrublands. Elsevier, Amsterdam

Trabaud L, Galtié JF (1996) Effects of fire frequency on plant communities and landscape pattern in the Massif des Aspres (southern France). Landscape Ecol 4:215-224. doi:10.1007/BF02071812

Usher MB (1981) Modelling ecological succession with particular reference to Markovian models. Vegetatio 46:1118. doi:10.1007/BF00118380

Vicente AM, Alés RF (2006) Long term persistence of dehesas. Evidences from history. Agrofor Syst 67:19-28. doi: 10.1007/s10457-005-1110-8

Walsh TA, Burk TE (1993) Calibration of satellite classifications of land area. Remote Sens Environ 46:281-290. doi: 10.1016/0034-4257(93)90048-3

Werner C, Correia O, Ryel RJ et al (1998) Modeling wholeplant primary production of macchia species: assessing the effects of photoinhibition and foliage orientation. Rev Biol 16:247-257

Westoby M, Walker B, Noy-Meir I (1989) Opportunistic management for rangelands not at equilibrium. J Range Manage 42:266-274. doi:10.2307/3899492 